\title{
Influence of Health and Safety Training, Safety Monitoring and Enforcement of Compliance on Employee Efficiency in Manufacturing Firms
}

\author{
Morgan Morgan Obong ${ }^{1}$, Christian Amadi $^{2}$, Okon Emmanuel Ekpenyong ${ }^{1}$, Emu Winifred Harry ${ }^{3} \&$ Hope Ukam \\ Edodi $^{1}$ \\ ${ }^{1}$ Department of Business Management, Faculty of Management Sciences, University of Calabar, Calabar, Nigeria \\ ${ }^{2}$ Department of Business Administration, Federal University, Wukari, Nigeria \\ ${ }^{3}$ Department of Educational Management, Faculty of Education, University of Calabar, Calabar, Nigeria \\ Correspondence: Morgan Morgan Obong, Department of Business Management, Faculty of Management Sciences, \\ University of Calabar, Calabar, Cross River State, Nigeria. Tel: 234-817-319-4049. E-mail: \\ m_morgan24@yahoo.com
}

Received: October 13, 2020

Accepted: December 23, 2020

Online Published: January 14, 2021

doi:10.5430/rwe.v12n2p86

URL: https://doi.org/10.5430/rwe.v12n2p86

\begin{abstract}
The purpose of the study is to investigate the influence of health and safety training, safety monitoring, and enforcement of compliance on employee efficiency in manufacturing firms. The research employed the quantitative approach involving a descriptive survey. A sample size of 360 respondents was randomly selected for the study. A questionnaire instrument was used in gathering primary data for the study. Confirmatory Factor Analysis (CFA) was used in providing a comprehensive validation of the measurement instrument. The required inferential statistics including normality, multicollinearity, and heteroscedasticity tests were performed and were satisfactory. Structural Equation Model (SEM) was used to estimate structural relationships between health and safety training, safety monitoring and enforcement of compliance on employee efficiency. The research results showed that health and safety training has a significant positive effect on employee efficiency with a p-value of 0.000 ; safety monitoring has a significant positive effect on employee efficiency with a p-value of 0.000 and enforcement of compliance has a significant positive effect on employee efficiency with a p-value of 0.000 . The research brings to the fore and creates awareness on the influence of health and safety training, safety monitoring, and enforcement of compliance to safety and health standard towards enhancing workers' safety, health and welfare for improved employee efficiency. Manufacturing firms should ensure adequate health and safety training and proper safety monitoring and enforcement of compliance to safety and health standard to reduce accidents and improve employee efficiency and performance.
\end{abstract}

Keywords: health, safety training, safety monitoring, enforcement, compliance, employee efficiency

\section{Introduction}

Over the years, lack of safety monitoring and compliance to safety rule coupled with poor knowledge of workers on safety procedures and standards due to perceived lack of health and safety training in manufacturing firms have continued to impede on employees efficiency; increase accidents; and absenteeism rate; and impacts negatively on the overall productivity of firms. Safety monitoring and enforcement of compliance play a vital role in ensuring workers compliance with safety regulations and stipulates safety inspection and sanctions for lack of adherence to safety guidelines. (Michael et al., 2006). Effective monitoring and compliance with safety rules are significant to accidents reduction in firms and enhanced workers' confidence at the workplace that leads to an improved efficiency and productivity. However, lack of adequate health and safety training has continued to be a major factor in health and safety management in many organizations. Health and safety training is significant to organization health and safety management because of its importance in improving workers' knowledge of health and safety challenges in organizations; and creates awareness on the dangers in the work environment which leads to a reduction in the rate of accidents and enhanced employees efficiency. 
Safety and health training is an aspect of safety and health management which outlines the procedure/strategies for safety training, the intervals, location, and safety training facilities required to develop the skills and knowledge of employees to carry out tasks safely without accidents and injuries to improve employees efficiency and productivity (Ahmad et al., 2013). Adequate health and safety training enhances employees' safety practices, behavior, and knowledge to carry out the assigned task safely without accidents. Effective safety and health training enhance workers' confidence due to the understanding of the dangers in the work environment and the knowledge of how to work safely without accidents or injuries which improves workers' efficiency and productivity (Cohen \& Colligan, 1998).

However, in Nigeria, the decreasing employees' efficiency, especially in manufacturing firms, has continued to be of concern to academia, public and private sectors alike. This decline in employees' efficiency in manufacturing firms has been on the rise globally and in the African continent in particular (Katsuro, Gadzirayi, Taruwona \& Mupararano, 2010). In recent times, several workers in manufacturing firms have been briefly or perpetually incapacitated by industrial mishaps, injuries, respiratory disease, heat, cancer, and other illness which impede on workers' health, safety, efficiency and productivity due to poor safety and health training and lack of safety monitoring and compliance to safety regulations to improve workers knowledge and awareness to work safely and enhanced efficiency (Reese, 2018).

All enterprises have the legal obligation of ensuring the safety and welfare of their workers. Observably, workers in manufacturing firms in Nigeria encountered numerous dangers and other challenges that affect their health and safety such as extreme noise, dust, heat, and circumstances that resulted in injuries and disease to workers bringing about a decrease in employees' efficiency. Despite the apparent need to manage safety and health training and safety monitoring proactively, manufacturing firms in Nigeria are yet to resolve the challenges of employees' safety and health adequately. This situation has led to repeated accidents, injuries, illnesses, and absences from work, resulting in loss of production time, reduction in workers efficiency, compensation for hospitalized workers, poor workers commitment, low output and decreased productivity. Additionally, poorly designed workstation and management inaction in providing regular safety training on the proper use of personal protective equipment as well as poorly ventilated factories in manufacturing firms has posed serious challenges to workers' health and safety which influences employees' efficiency (Boyle, 2012; Akpan, 2011).

Providing a safe and healthy workplace in manufacturing firms is often a challenge due to a lack of commitment to the implementation and management of safety and health training and proper monitoring of compliance to safety regulations (Akpan, 2011). In addition, the none adherence to health and safety rules and workers ignorance of the imminent dangers associated with the poor manufacturing environment as well as poor safety behavior and knowledge due to inadequate safety and health training, work-related accidents and disease are on the increase in most manufacturing firms (Fuller \& Vassie, 2004). This phenomenon has a behavioral consequence on the safety consciousness and efficiency of employees. Although management of manufacturing firms have consistently laid claims on their efforts to providing health and safety training; and ensuring proper monitoring and enforcement of compliance to safety standards towards guaranteeing safe conditions of work and improve workers efficiency; accidents have remained on the rise which indicates that the occupational environment is still perilous and impacts on employees' efficiency. This situation has raised questions on the extent of safety and health training, safety monitoring, and enforcement of compliance with safety standards on employees' efficiency in manufacturing firms. Therefore, the purpose of this study is to examine the influence of health and safety training, safety monitoring, and enforcement of compliance to safety standards on employees' efficiency of manufacturing firms in Nigeria. First, it was hypothesized that $\left(\mathrm{H}_{1}\right)$ health and safety training has a significant effect on employee efficiency. Second, $\left(\mathrm{H}_{2}\right)$ safety monitoring has a significant effect on employee efficiency. Third, $\left(\mathrm{H}_{3}\right)$ enforcement of compliance has a significant effect on employee efficiency. The study was organized as follows; first, the introduction was followed by second, the literature review on the constructs under study. Third, was the methods; which considered issues such as the study population, sample, measurement, and Confirmatory Factor Analysis (CFA); Fourth, was the results, followed by discussion and conclusion of the study.

\section{Literature Review}

\subsection{Health and Safety Training}

Health and safety training is a process of providing required safety education to improve workers' skills and knowledge that will influence workers' behavior and work practices to carry out the assigned task safely to avoid accidents, enhance workers' confidence and improve efficiency (Mashi, Subramaniam \& Johari., 2016). Health and safety training is a critical component of an organization's safety management which outlines the procedure for 
training and orientation programs, the safety training interval, location, and facilities required for successful safety training. It is a procedure that is targeted at enhancing employees' abilities to carry out tasks safely (Michael et al., 2006). Education and instruction are essential techniques for raising employees' awareness of occupational dangers in the work setting. It enhances the comprehension of employees on the strategies to work safely and avoid risky behaviors that may lead to accidents and endanger workers' health and safety (Fuller \& Vassie, 2004). Health and safety training is a crucial part of preventive programs that starts as part of the induction/orientation following the recruitment of new employee or departmental transfers in most organizations to equip employees with the needed skills, knowledge, and expertise to carry out assigned task safely and improve employees efficiency. Health and safety education has to do with improving the abilities, understanding, and attitudes of employees to become more productive and perform assigned tasks safely (Armstrong, 2010).

Safety and health training is a vital risk avoidance strategy towards ensuring safe workplace conditions. According to Boyle (2012), knowledge of safety education is vital in identifying and managing dangers in the workplace adequately. Training has been identified as an impeccable aspect of any safety management in the organization and helps build workers' capacity to work based on safety guidelines (Umugwaneza, Nkechi \& Mugabe, 2019). Similarly, a standard method to inspire good work behavior is for the organization to put in place a safety education and training program. Health and safety training centers on creating awareness, enhancing employees' knowledge, work behavior/practice, and understanding of the work environment to avert incidence and accident with significant benefit to employers and employees. Umeokafor, Isaac, Jones and Umeadi (2014) emphasized the importance of training to complement employees' skills, enhance efficiency and improve the safety consciousness of workers to carry out tasks safely. Safety and health training could be on the job or off the job depending on the training needs of the employees; it could also be given through induction/orientation, coaching and mentoring, etc.

Similarly, health and safety education is essential and has been an indispensable segment of work-related health and safety management in recent times. It is dependent upon the employers to provide essential guidelines and training, assessing the capabilities of each employee to utilize what was learned during safety and health training when working (Ali, 2016). Armstrong (2010) opines that organizations should have health and safety training programs that covers site evaluation and orientation where necessary. The safety and health training program should cover explicit areas, for example, accident control techniques, emergency drills, awareness on the use of personal protective equipment (PPEs), accident reporting, work practice behavior, and safety consciousness, etc. Effective health and safety training can reduce injuries, accidents, deaths, property damage and legal liabilities, absenteeism, and enhance employees' confidence, efficiency, and productivity (Fuller, 2019).

Safety education enables staff to obtain better abilities to perform assigned duties safely without accidents and improve workers' efficiency. Consistent with these views, Bankole and Ibrahim (2012) noted that safety education should incorporate all employees to increase their knowledge and safety behavior. Furthermore, study by Mubashar, Mufi and Amjad (2013) indicated that safety training influence the safety culture and behavior of construction workers. Also, Boini, Colin, and Grzbyk (2017) indicated that occupational safety and health education leads to reduction on the incidence of workplace injuries and improve workers performance. Similarly, Amponsah-Tawiah and Mensah (2016) indicated that occupational health and safety has significant relationship with organizational commitment and enhance performance. Regular safety and improved education of employees improve safety awareness, reduce injuries, and enhance output in firms. Employees should be encouraged to develop a positive attitude towards occupational health and safety training as a way of mitigating the injuries that occur at workplaces for enhanced efficiency. Therefore, it is imperative for organizations, particularly manufacturing firms to give considerable attention to health and safety training in order to reduce accidents and improve employees' efficiency and productivity.

\subsection{Safety Monitoring and Enforcement of Compliance}

Safety monitoring and enforcement of compliance is a procedure for monitoring employees' safety behavior and work practice to ensure strict adherence to the firm's health and safety standards and regulations. Safety monitoring and enforcement of compliance is a vital part of a firm's safety management which stipulates the procedure for inspecting and compelling employees to observe safety guidelines in the work environment and initiation of a disciplinary procedure for defaulting employees (Agumba, Fester \& Haupt, 2011). Safety monitoring and enforcement are essential to ensure compliance with safe work procedures in organizations. One way of ensuring compliance with safety and health regulations is through active monitoring/inspection of compliance with safety rules. Compliance with safety regulations helps to build a philosophy of safety in enterprises to reduce the risk from failure to adhere to organizational safety guidelines (Chatburn, Macrae, Carthy \& Vincent, 2018). The purpose of 
safety monitoring and enforcement is to ensure that employees conform to safety regulations and those who fail to comply with safety rules are held accountable and disciplinary action is taken against them. Proper monitoring and enforcement of safety regulations reduce accidents, injuries, and illness in an organization and ensure workers' safety for improved efficiency and productivity.

To enforce control, it is essential to develop an effective monitoring team of experts towards ensuring adherence to safety guidelines in firms. The basic kinds of enforcement in safety administration are enforcement within the enterprise and government agencies. Within an organization, there are safety guidelines that workers are expected to follow strictly. Government agencies establish health and safety laws, acts, or regulations for companies to follow. When employers of labor fail to comply, they receive sanctions with accompanying fines. However, discipline is one of the most widely recognized methods utilized to lessen unsafe practices that may expose workers to danger at work (Gunningham, 2010). More so, proper monitoring/inspection of compliance with safety rules enhance the protection of workers from hazards in the workplace (Armstrong, 2010). The rate of compliance to safety guidelines could be influenced by the administrative technique of those saddled with the responsibility of ensuring employee safety, level of health and safety training, active safety monitoring, and other factors. It is of great importance for organizations to ensure strict monitoring and compliance to safety rules to reduce risky behavior, instill a culture of safety, discipline and ensure that workers carry out assigned duties safely to reduce accidents and enhance efficiency (Lun \& Wahab, 2017).

Occupational safety monitoring influence employee efficiency and is important that organizations carry out regular safety monitoring to ensure workers adherence to safety procedures (Lalis \& Vittek, 2014). Also, safety inspection could influence the rate of accidents and absenteeism in firms. Thus, it is pertinent for organizations to carry out regular inspections of factories to identify hazardous substances that could cause accidents in order to institute preventive measures (Yao, Zhu, Jiang \& Xia, 2013). Similarly, compliance with risk control measures and protective equipment could lead to accidents reduction in firms (Wambulwa, Makokha \& Namusonge, 2018). Therefore, organizations should budget adequate funds for safety management, ensure availability of protective equipment for all employees and strict compliance to safety regulations to protect workers from accidents (Akpan, 2011).

\subsection{Employee Efficiency}

Employee efficiency is the speed, accuracy, commitment, productivity, and overall performance of an employee in accomplishing an assigned task within a specified period without accidents and wastage of materials in producing the desired output efficiently (Armstrong, 2010). Employees are a significant component of any enterprise; therefore, organizations need to focus on enhancing their wellbeing and security. This is imperative to ensuring a safe working environment to enhance employees' efficiency. Effective health and safety training and proper monitoring and compliance with safety regulations provide comfort, reduce accidents, and increases employees' performance (Yusuf, Eliyana \& Sari, 2012). When the management of an organization is committed to their employees' welfare and security, then it is anticipated that the occurrence of occupational hazards in the work environment will be reduced. Organizations that invest in employees' health and safety training and ensures strict compliance with safety standards may benefit significantly on improved efficiency and organizational performance (Tengilimoglu, Celik \& Guzel, 2016).

However, organizations are established with specific goals and objectives to accomplish. This aims can be realized by utilizing the resource in the organization such as men (employees) machines and materials. All these resources are essential, but employees are the most important because they play a vital role to integrate the other component in performing a task for the accomplishment of organizational goals and objectives. Technology alone cannot bring about the desired change in employee efficiency without adequate health and safety training and education to improved workers knowledge, work behavior/practices and protect them from accidents in an organization. Management of organizations must, therefore, be aware of the health and safety training needs of their employees to increase efficiency and performance (Yusuf, et al., 2012).

Employees' ability to perform efficiently on the job depends on their understanding of the job description, level of training, the safety and comfort of the workplace, and how the employees are motivated to perform assigned tasks (Armstrong, 2010). Therefore, management cannot afford to ignore employees' health, safety, and welfare at any cost, because employees are the principal component of any organization. The contribution of employees on the job is the most critical factor for the development and progress of an organization, as such, it is important to ensure adequate protection of employees to enhance their efficiency.

Attempts have been made to review extant literature on health and safety training, safety monitoring, enforcement of 
compliance, employee efficiency and related concepts. However, the review of prior extant empirical literature has indicated a literature gap, which this research intends to fill. Studies by Cohen and Colligan (1998); Michael et al. (2006); Akpan (2011); Agumba, Fester, and Haupt (2011); Bankole and Ibrahim (2012); Mubashar, Mufi and Amjad (2013); Yao et al. (2013); Umeokafor, Isaac, Jones, and Umeadi (2014); Amponsah-Tawiah and Mensah (2016); Mashi, Subramaniam and Johari (2016); Boini, Colin and Grzbyk (2017); Chatburn, et al. (2018); Umugwaneza, Nkechi and Mugabe (2019) etc., have found significant relationship using different dimensions of safety and health on employees' performance in different sectors and countries context. However, little or no attention had been made by previous studies on the influence of health and safety training, safety monitoring and enforcement of compliance on employee efficiency in manufacturing firms in developing countries context, particularly, Nigeria. Therefore, this study aims to bridge this gap and contribute to current knowledge on health and safety training, safety monitoring, enforcement of compliance and employee efficiency relationship in manufacturing firms.

\section{Method}

The research employed the quantitative approach involving a descriptive survey design. The population of the study comprised 500 employees from six manufacturing firms in the Southern region, Nigeria. A sample size of 360 employees was randomly selected from the six selected firms. A questionnaire instrument was developed and used in gathering primary data from the selected manufacturing firms for the study. The instrument covers the constructs of the study (health and safety training, safety monitoring, enforcement of compliance, and employee efficiency). However, to validate the measurement instrument, Confirmatory Factor Analysis (CFA) was used. The scored data of each construct were used in analyzing the study. After data screening, identification, and replacement of missing values using serial mean substitution and outliers analysis using Mahalanobis Distance $\mathrm{D}^{2}$ (Hair, Black, Babin \& Anderson, 2010). The analysis revealed a $\mathrm{D}^{2}$ probability above 0.001 for 13 values, which indicated 13 outliers from the data set. The 13 identified outliers were deleted to ensure that the data set was free from outliers. The remaining 347 values were retained and used for further analysis in the research. To examine the influence of health and safety training, safety monitoring, and enforcement of compliance on employee efficiency and to ensure that the assumptions of the analysis were satisfactorily meet, several inferential statistics were performed, including normality, multicollinearity, and heteroscedasticity tests. However, Structural Equation Model (SEM) was used to estimate structural/causal relationships between health and safety training, safety monitoring, and enforcement of compliance on employee efficiency.

\section{Results}

\subsection{Confirmatory Factor Analysis (CFA)}

To ascertain if the measures of the constructs are consistent and the data fit the measurement model, CFA was used to validate the instrument. In CFA, items with factor loading less than $(<0.50)$ were deleted from the model. However, to achieve the model fit, one item in health and safety training, safety monitoring and employee efficiency constructs were deleted while two items were deleted from enforcement of compliance construct due to low factor loading. In CFA analysis, it is important to report the Root Mean Square Error of Approximation (RMSEA), Comparative Fit Index (CFI), Chi-Square test ( $\chi 2$ ), and Standardized Root Mean Square Residual (SRMR) to determine the goodness of fit of the measurement model (Kline, 2015; Brown, 2015). After the deletion, all the indices revealed that the model achieve goodness of fit $(\chi 2 / \mathrm{df}=2.42$, $\mathrm{RMSEA}=0.062, \mathrm{CFI}=0.931$ and SRMR $=0.071)$. All the indices meet the recommended cut-off marks and were acceptable $(\chi 2 / \mathrm{df}<3$, RMSEA $<0.08$, CFI $>0.9$ SRMR $<.08)$ (Kline, $2015)$. All the retained factor loading items exceeded the acceptable threshold of $(>0.50)$. The Cronbach's alpha values ranged from 0.773-0.869 and were acceptable since the alpha values meet the recommended internal consistency value of (>0.60) (Hair et al., 2010). The Composite Reliability (CR) values ranged from 0.742-0.877, and the Average Variance Extracted (AVE) ranged from 0.521-0.667 and were all acceptable as the obtained values exceeded the recommended values of $(>0.60$ and $>0.50)$ respectively in all the constructs, indicating that the model satisfactorily meets the recommended threshold. The summary of CFA result for all the constructs is presented in Table 1. 
Table 1. Summary of confirmatory factor analysis result

\begin{tabular}{|c|c|c|c|c|c|}
\hline \multirow[b]{2}{*}{ Constructs } & \multicolumn{5}{|c|}{ Cronbach } \\
\hline & Item & Factor loading & alpha & $\mathrm{CR}$ & AVE \\
\hline & & & 0.854 & 0.821 & 0.557 \\
\hline \multirow[t]{5}{*}{ Health and safety training (HST) } & HST 1 & 0.82 & & & \\
\hline & HST 2 & 0.79 & & & \\
\hline & HST 3 & 0.77 & & & \\
\hline & HST 4 & Deleted & & & \\
\hline & HST 5 & 0.75 & 0.773 & 0.822 & 0.521 \\
\hline \multirow[t]{5}{*}{ Safety monitoring (SM) } & SM 6 & 0.74 & & & \\
\hline & SM 7 & 0.77 & & & \\
\hline & SM 8 & Deleted & & & \\
\hline & SM 9 & 0.83 & & & \\
\hline & SM 10 & 0.851 & 0.832 & 0.822 & 0.576 \\
\hline \multirow[t]{6}{*}{ Enforcement of compliance (EC) } & EC 11 & 0.77 & & & \\
\hline & EC 12 & Deleted & & & \\
\hline & EC 13 & 0.86 & & & \\
\hline & EC 14 & 0.75 & & & \\
\hline & EC 15 & Deleted & & & \\
\hline & EC 16 & 0.89 & 0.822 & 0.742 & 0.546 \\
\hline \multirow[t]{6}{*}{ Employee efficiency (EE) } & EE 1 & 0.86 & 0.869 & 0.877 & 0.667 \\
\hline & EE 2 & 0.88 & & & \\
\hline & EE 3 & 0.84 & & & \\
\hline & EE 4 & 0.87 & & & \\
\hline & EE 5 & 0.88 & & & \\
\hline & EE 6 & Deleted & & & \\
\hline \multicolumn{6}{|c|}{ Comparative Fit Index $(\mathrm{CFI})=0.931 ;$ Standardized Root Mean Square Residual $(\mathrm{SRMR})=0.071$} \\
\hline
\end{tabular}

Table 2 presents the result of descriptive statistics. The analysis revealed a sample of (N) 347 in all constructs. The health and safety training construct had a minimum and maximum values of 1 and 5 . The construct had a mean average value of 4.164 with standard deviation and variance values of 1.847 and 3.410 respectively. The safety monitoring construct had an average value of 1 and 5 for minimum and maximum. A mean average value of 4.661 with standard deviation and variance values of 1.594 and 2.540 respectively. Similarly, enforcement of compliance had a minimum and maximum values of 1 and 5. The variable had a mean average value of 4.272 with standard deviation and variance values of 1.604 and 2.573 respectively. The descriptive statistics analysis further showed that the employee efficiency construct had a minimum and maximum values of 1 and 5. The construct had a mean average value of 4.366 with standard deviation and variance values of 2.690 and 7.238 respectively. 
Table 2. Result of descriptive statistics

\begin{tabular}{lcccccc}
\hline \multicolumn{1}{c}{ Constructs } & N & Minimum & Maximum & Mean & $\begin{array}{c}\text { Std. } \\
\text { Deviation }\end{array}$ & Variance \\
\hline Health and safety training & 347 & 1 & 5 & 4.164 & 1.847 & 3.410 \\
Safety monitoring & 347 & 1 & 5 & 4.661 & 1.594 & 2.540 \\
Enforcement of compliance & 347 & 1 & 5 & 4.272 & 1.604 & 2.573 \\
Employee efficiency & 347 & 1 & 5 & 4.366 & 2.690 & 7.238 \\
Valid N (listwise) & 347 & & & & & \\
\hline
\end{tabular}

\subsection{Normality Test}

To determine the normality of the distribution, the Kolmogorov-Smirnov and Shapiro-Wilk tests were used to determine whether the sample population is normally distributed. As a rule of thumb, if the significant values of Kolmogorov-Smirnov and Shapiro-Wilk tests are greater than 0.05, the data is normally distributed but if below 0.05 , it indicates that the data significantly deviated from a normal distribution (Hair et al., 2010). Also, Davcik (2014) indicated that the absolute values of skewness and kurtosis of the distribution should not exceed 1.00 and 2.00 respectively. Table 3 presents the result of the normality test. The results showed that the Kolmogorov-Smirnov significant values were all greater than $0.05(0.077,0.064$, and 0.057$)$ and the Shapiro-Wilk significant values were also above $0.05(0.086,0.076$, and 0.051$)$ in health and safety training, safety monitoring, and enforcement of compliance respectively indicating that the data were normally distributed. Also, skewness of the distribution revealed the following values (-.106, -..128, and -.104) and the kurtosis values were (-.198, -.181 and-.247), based on the rule of thumb, since the skewness and kurtosis of the distribution did not exceed 1.00 and 2.00 respectively, it was an indication that the data was normally distributed.

Table 3. Summary of normality test result

\begin{tabular}{|c|c|c|c|c|c|c|c|c|c|}
\hline & \multicolumn{4}{|c|}{ Kolmogorov-Smirnov } & \multicolumn{3}{|c|}{ Shapiro-Wilk } & \multirow[b]{2}{*}{ skewness } & \multirow[b]{2}{*}{ Kurtosis } \\
\hline & Constructs & Statistic & Df & Sig. & Statistic & df & Sig. & & \\
\hline \multirow[t]{3}{*}{$\begin{array}{l}\text { Employee } \\
\text { efficiency }\end{array}$} & $\begin{array}{l}\text { Health and safety } \\
\text { training }\end{array}$ & . 182 & 347 & .077 & .982 & 347 & .086 & -.106 & -.198 \\
\hline & $\begin{array}{l}\text { Safety } \\
\text { Monitoring }\end{array}$ & . 180. & 347 & .064 & 984 & 347 & .076 & -.128 & -.181 \\
\hline & $\begin{array}{l}\text { Enforcement of } \\
\text { compliance }\end{array}$ & 207 & 347 & .057 & 987 & 347 & .051 & -.104 & -.247 \\
\hline
\end{tabular}

a. Lilliefors Significance Correction

*. This is the lower bound of the true significance

\subsection{Multicolinearity Test}

To determine the intercorrelation between the variables, a multicollinearity test was executed using tolerance and Variance Inflation Factor (VIF) to see if there were very high intercorrelations among the predictor variables. The rule of thumb is that tolerance should be greater than 0.2 and VIF should be less than 5.0 (Hair et al., 2010). Table 4 presents the result of the multicollinearity test. The results revealed the tolerance values of $(0.499,0.472$, and 0.697$)$ and VIF values of $(1.507,1.691$, and 1.435) in health and safety training, safety monitoring and enforcement of compliance respectively. Since the tolerance values were all greater than 0.2 and the VIF were less than 5.0, the result indicated that there are no multicollinearity issues among the independent variables. Also, the Eigenvalues of $(.154, .142$, and .151) were not close to zero across all variables and the Condition Index Values (CIV) of (7.325, 9.057, and 11.871) were all less than the cut of mark of 15 which further confirm that there were no multicollinearity issues among the independent variables. 
Table 4. Summary of multicollinearity test result

\begin{tabular}{|c|c|c|c|c|c|c|c|c|c|c|}
\hline \multirow{3}{*}{\multicolumn{2}{|c|}{ Model }} & \multicolumn{5}{|c|}{ Coefficients $^{\mathrm{a}}$} & & & & \\
\hline & & \multicolumn{2}{|c|}{$\begin{array}{l}\text { Unstandardized } \\
\text { Coefficients }\end{array}$} & \multirow{2}{*}{$\begin{array}{c}\text { Standardized } \\
\text { Coefficients } \\
\text { Beta }\end{array}$} & \multirow[b]{2}{*}{$\mathrm{t}$} & \multirow[b]{2}{*}{ Sig. } & \multicolumn{2}{|c|}{$\begin{array}{l}\text { Collinearity } \\
\text { Statistics }\end{array}$} & \multirow{2}{*}{$\begin{array}{l}\text { Eigen } \\
\text { Values }\end{array}$} & \multirow[b]{2}{*}{ CIV } \\
\hline & & B & Std. Error & & & & Tolerance & VIF & & \\
\hline \multirow[t]{4}{*}{1} & (Constant) & 8.188 & 1.236 & & 6.626 & .000 & & & & \\
\hline & $\begin{array}{l}\text { Health and safety } \\
\text { training }\end{array}$ & .423 & .059 & .290 & 7.190 & .000 & .499 & 1.507 & .154 & 7.325 \\
\hline & Safety Monitoring & .351 & .071 & .208 & 4.966 & .000 & .472 & 1.691 & .142 & 9.057 \\
\hline & $\begin{array}{l}\text { Enforcement of } \\
\text { compliance }\end{array}$ & .896 & .051 & .534 & 17.496 & .000 & .697 & 1.435 & .151 & 11.871 \\
\hline
\end{tabular}

a. Dependent Variable: Employee efficiency

\subsection{Heteroscedasticity Test}

To determine whether there is a variance inequality of the residual among the observations periods, the heteroscedasticity test was performed. In particular, the Glejser test was used to determine the presence or absence of heteroscedasticities. As a rule of thumb in heteroscedasticity with test Glejser, if the significant values are greater than 0.05 , then there are no heteroscedasticity issues, but if the significant value is less than 0.05 there are heteroscedasticity problems. Table 5 present the result of the heteroscedasticity test. The result indicated that the obtained values of significance for health and safety training, safety monitoring, and enforcement of compliance constructs were $(0.183,0.246$, and 0.247$)$ respectively which were all greater than 0.05 . Based on this result it was concluded that there are no heteroscedasticity issues.

Table 5. Heteroscedasticity test result

\begin{tabular}{|c|c|c|c|c|c|c|}
\hline \multicolumn{7}{|c|}{ Coefficients $^{\mathrm{a}}$} \\
\hline & & $\begin{array}{r}\text { Unstand } \\
\text { Coeffi }\end{array}$ & $\begin{array}{l}\text { rdized } \\
\text { ients }\end{array}$ & $\begin{array}{l}\text { Standardized } \\
\text { Coefficients }\end{array}$ & & \\
\hline \multicolumn{2}{|l|}{ Model } & B & Std. Error & Beta & $\mathrm{T}$ & Sig. \\
\hline \multirow[t]{4}{*}{1} & (Constant) & -3.176 & 1.113 & & -2.854 & .138 \\
\hline & $\begin{array}{l}\text { Health and safety } \\
\text { training }\end{array}$ & .252 & .568 & .081 & .443 & .183 \\
\hline & Safety monitoring & .143 & .482 & .073 & .297 & .246 \\
\hline & $\begin{array}{l}\text { Enforcement } \\
\text { compliance }\end{array}$ & .134 & .364 & .091 & .368 & .247 \\
\hline
\end{tabular}

a. Dependent Variable: Absolute R

\subsection{Structural Equation Modelling}

To examine the relationship between health and safety training, safety monitoring, and enforcement of compliance on employee efficiency, Structural Equation Modelling (SEM) was used. The SEM analysis is a multivariate approach used in examining structural relationships among constructs in a study (Kline, 2015). To examine the pattern of the relationship between health and safety training, safety monitoring, and enforcement of compliance on employee efficiency the path analysis was used to show the direct influence of the independent constructs (health and safety training (HST), safety monitoring (SM), and enforcement of compliance (EC) on employee efficiency (EE). The path diagram in figure 1 shows the standardized regression weights estimates of the relationship between health and safety training, safety monitoring, and enforcement of compliance on employee efficiency. The path diagram revealed that health and safety training impacted employee efficiency by $36 \%$. This implies that adequate health and 
safety training in manufacturing firms has a $36 \%$ influence on employee efficiency. Similarly, safety monitoring impacted employee efficiency by $26 \%$. This indicated that proper safety monitoring in manufacturing firms has a $26 \%$ influence on employee efficiency. Also, enforcement of compliance impacted employee efficiency by $67 \%$. This implies that adequate enforcement of compliance with safety standards in manufacturing firms has a $67 \%$ influence on employee efficiency.

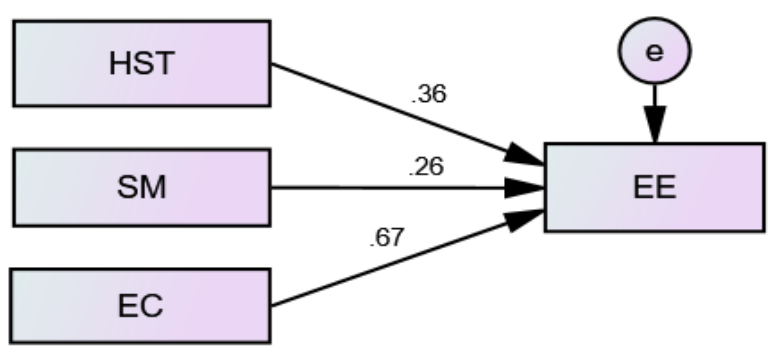

Figure 1. Path diagram showing standardized regression weights estimates of the relationship between Health and Safety Training (HST), Safety Monitoring (SM) and Enforcement of Compliance (EC) on Employee Efficiency (EE)

Table 6 presents the summary of the direct influence of health and safety training, safety monitoring, and enforcement of compliance on employee efficiency. Table 6 revealed that the direct effect of health and safety training on employee efficiency was significant at $0.423(\mathrm{p}=0.00)$. This implies that a $1 \%$ increase in health and safety training, will result in a $0.423 \%$ increase in employee efficiency. Therefore, hypotheses $\left(\mathrm{H}_{1}\right)$ was supported that health and safety training has a significant effect on employee efficiency. Second, the direct effect of safety monitoring on employee efficiency was significant at $0.351(\mathrm{p}=0.00)$. This implies that when safety monitoring increase by $1 \%$, employee efficiency increases by 0.351 . Based on the result, hypotheses $\left(\mathrm{H}_{2}\right)$ was supported that safety monitoring has a significant effect on employee efficiency. Third, the direct effect of enforcement of compliance on employee efficiency was significant at $0.896(\mathrm{p}=0.00)$. This implies that when enforcement of compliance increase by $1 \%$, employee efficiency increases by $0.896 \%$. Based on this result, hypotheses $\left(\mathrm{H}_{3}\right)$ was supported that enforcement of compliance has a significant effect on employee efficiency. Explicitly, the result of the study revealed that health and safety training, safety monitoring, and enforcement of compliance has a significant effect on employee efficiency in manufacturing firms.

Table 6. Summary of direct influence of health and safety training, safety monitoring and enforcement of compliance on employee efficiency

\begin{tabular}{llrlrrrrr}
\hline Hypotheses & Constructs & Path & Constructs & Estimate & S.E. & C.R. & P-value & Result \\
\hline $\mathrm{H}_{1}$ & $\begin{array}{l}\text { Employee } \\
\text { efficiency (EE) }\end{array}$ & $<---$ & $\begin{array}{l}\text { Health and safety } \\
\text { training (HST) }\end{array}$ & .423 & .037 & 11.434 & 0.00 & Significant \\
$\mathrm{H}_{2}$ & $\begin{array}{l}\text { Employee } \\
\text { efficiency (EE) }\end{array}$ & $<--\begin{array}{l}\text { Safety } \\
\text { monitoring (SM) }\end{array}$ & .351 & .043 & 8.182 & 0.00 & Significant \\
$\mathrm{H}_{3}$ & $\begin{array}{l}\text { Employee } \\
\text { efficiency (EE) }\end{array}$ & $<--\begin{array}{l}\text { Enforcement of } \\
\text { compliance (EC) }\end{array}$ & & .896 & .043 & 21.047 & 0.00 & Significant \\
\hline
\end{tabular}

Table 7 presents a summary of the goodness of fit indexes of the measurement model for health and safety training, safety monitoring, and enforcement of compliance constructs on employee efficiency. The indices from Table 7 indicated that the measurement model achieved the overall goodness of fit. 
Table 7. Summary of goodness of fit indexes of the measurement model

\begin{tabular}{ccccccc}
\hline Model & Chisq/df & RMSEA & CFI & GFI & AGFI & p-value \\
\hline $\begin{array}{c}\text { Direct effect of the } \\
\text { constructs }\end{array}$ & 2.471 & 0.074 & 0.944 & 0.941 & 0.971 & .000 \\
\hline
\end{tabular}

Table 7 revealed Chi-square df value of $\left(\chi^{2} / \mathrm{df}=2.471\right)$, root mean square error of approximation value of (RMSEA $=0.074)$, comparative fit index value of $(\mathrm{CFI}=0.944)$, goodness of fit index value of $(\mathrm{GFI}=0.941)$, adjusted goodness of fit index values of $(\mathrm{AGFI}=0.971)$ and a Probability value of $(\mathrm{p}=0.000)$, which achieve the acceptable cut-off values and were all satisfactory as recommended $(\chi 2 / \mathrm{df}<3$, RMSEA $<0.08$, CFI $>0.9$, GFI $>0.9$, AGFI $>0.9$ and p-value<0.05) (Hurber-Carol, Balakrishman, Nikulin \& Mesbah, 2002). This result supported the hypotheses of the study and affirm that health and safety training, safety monitoring, and enforcement of compliance has a significant positive effect on employee efficiency of manufacturing firms in Nigeria.

\section{Discussion}

\section{Health and safety training has a significant positive effect on employee efficiency.}

The results of the analysis in this study revealed that health and safety training has a significant positive effect on employee efficiency of manufacturing firms in Nigeria. The finding was reached after the analysis of the direct influence of health and safety training on employee efficiency revealed an estimated value of 0.423 and a p-value of 0.000 which was statistically significant. The estimated value of 0.423 indicated that a percentage increase in health and safety training will result in a $0.423 \%$ increase in the employee efficiency of manufacturing firms. Also, the standardized regression weights estimate in the path diagram revealed a value of $36 \%$ which implies that health and safety training construct impacted employee efficiency of manufacturing firms by $36 \%$. This result was supported by the study of Mashi et al. (2016) who found that safety training impact significantly on employee performance and as well play a vital role in enhancing employees' skills and safety behavior which leads to a reduction on the rate of accidents, increase workers confidence and performance. Adequate safety and health training could lead to a significant improvement in the capabilities of employees which will have a multiplier effect on employee skills and efficiency thereby improving productivity and performance of the firm (Michael et al., 2006). Further, Umugwaneza et al. (2019) indicated that enhanced and consistent health and safety training could lead to a significant reduction in accident rate, material wastages, absenteeism, and compensation to hospitalize employees' thereby improving workers efficiency, productivity, and the firm's profitability.

\section{Safety monitoring has a significant positive effect on employee efficiency.}

The safety monitoring construct has a significant positive effect on employee efficiency. Thus, the result was in accordance with the initial hypothesis $\left(\mathrm{H}_{2}\right)$ which states that safety monitoring has a significant effect on employee efficiency. The result was evidenced by an estimated value of 0.351 which was statistically significant at a p-value of 0.000 . The estimated value of 0.351 implies that a unit increase in safety monitoring will result in a 0.351 percent increase in the efficiency of the employee in manufacturing firms. Further, the standardized regression weights estimate in the path diagram revealed a value of $26 \%$ implying that safety monitoring constructs impacted the efficiency of the employee in manufacturing firms by $26 \%$. The result was in line with the study of Agumba et al. (2011), who indicated that safety monitoring impacted employees' safety consciousness and performance and as well enhance the evaluation of the effectiveness of health and safety programs. The result corroborates the work of Chatburn et al. (2018), who made a similar conclusion in his study that proper safety monitoring has a positive effect on workers safety behavior and as well help in identifying underlying safety and health problems, detect at-risk practice of workers and the extent of compliance to safety measures. Also, the result aligns with the study of Lalis and Vittek (2014) that safety monitoring influence employee performance and work habit and as well enhance the review of the effectiveness of a firm's safety systems.

\section{Enforcement of compliance has a significant effect on employee efficiency.}

The result of the hypothesis $\left(\mathrm{H}_{3}\right)$ revealed that enforcement of compliance has a significant positive effect on employee efficiency. The finding was reached after the analysis of the direct influence of enforcement of compliance on employee efficiency revealed an estimated value of 0.896 and a p-value of 0.000 which was statistically significant. The estimated value of 0.896 indicated that a $1 \%$ increase in enforcement of compliance will result in a $0.896 \%$ increase in the employee efficiency of manufacturing firms. Also, the standardized regression weights estimate in the path diagram revealed a value of $67 \%$ which implies that enforcement of compliance constructs 
impacted employee efficiency of manufacturing firms by $67 \%$. The result was supported by the study of Umeokafor et al. (2014) that enforcement of compliance to safety rules has a significant effect on accident reduction and enhance employee performance. Aligning with this finding also was the study of Gunningham (2010) that effective enforcement of compliance to rules is vital to the successful management of health and safety which improves employee confidence on the work environment and as well lead to increasing efficiency and productivity.

\section{Conclusions}

The increasing susceptible manufacturing environment coupled with other health and safety challenges which pose a serious threat to employee's efficiency, and productivity makes it imperative for organizations management to pay particular attention to issues surrounding health and safety training, safety monitoring, and enforcement of compliance to safety standard to improve employee efficiency and performance. The results of this study revealed that health and safety training has a significant positive effect on employee efficiency; safety monitoring has a significant positive effect on employee efficiency; and enforcement of compliance has a significant positive effect on employee efficiency. It is therefore concluded that a firm's health and safety training is to improve employees' knowledge, capabilities, skill, competency, innovativeness, and creativity required to perform efficiently, and as well improve workers' safety behavior and practices to reduce accidents and enhanced employee efficiency. Similarly, proper safety monitoring and compliance to health and safety standard are imperative to the attainment of safety goals of protecting the employee from accidents and enhancing their welfare for improved efficiency and performance. Therefore, it becomes critical for the management of organizations, particularly manufacturing firms to show commitment and place emphasis on effective health and safety training, safety monitoring, and enforcement of compliance to safety standards in order to improve employee efficiency and performance.

\section{Limitation and Suggestion for Future Study}

This study was not without limitations. First, the study was limited to three constructs; health and safety training, safety monitoring, and enforcement of compliance use in examining the influence on employee efficiency. Second, the research was culturally and geographically limited to manufacturing firms operating in the Southern region, Nigeria. Third, the study relied heavily on primary data which were obtained from a questionnaire instrument completed by employees based on their knowledge and perception of the firm's health and safety training, safety monitoring, and enforcement of compliance and employee efficiency. Future studies should seek to incorporate other variables that are capable of improving employee health, safety, and welfare for improved performance. Also, this research should be replicated in countries/regions with a different cultural background using a longitudinal survey to ascertain the validity and generalizability of the result of this study.

\section{References}

Agumba, J. N., Fester, F. C., \& Haupt, T. (2011). Proactive monitoring of health and performance in small and medium construction enterprise using leading health and safety indicators. CIB W099 Conference, Washington DC, USA.

Ahmad, S., Wazed, A., Khan, M., Faruquee, M., Yasmin, M., Rahman, M., \& Khandkar, S. (2013). Training manual on occupational safety and health. Department of Occupational and Environmental Health, National Institute of Preventive and Social Medicine Mahakhali, Dhaka. https://doi.org/10.13140/RG.2.2.27327.05280

Akpan, E. I. (2011). Effective safety and health management policy for improved performance of organizations in Africa. International Journal of Business and Management, 6(3), 159-165. Retrieved from www.ccsenet.org/ijbm

Ali, W. (2016). Understanding the concept of job satisfaction, measurements, theories and its significance in the recent organizational environment: A theoretical framework. Archives of Business Research, 4(1), 100-111. https://doi.org/10.14738/abr.41.1735

Amponsah-Tawiah, K., \& Mensah, J. (2016). Occupational health and safety and organizational commitment: Evidence from the Ghanaian Mining Industry. Safety and Health at Work, 7(3), 225-230. https://doi.org/10.1016/j.shaw.2016.01.002

Armstrong, M. (2010). Essential human resource management practice: A guide to people management. London: Konga Page.

Bankole, A. R., \& Ibrahim, L. O. (2012). Perceived influence of health education on occupational health of factory workers in Lagos, Nigeria. British Journal of Arts and Social Sciences, 8(1), 57-65. Retrieved from 
http://connection.ebscohost.com/c/articles/84687698

Boini, S., Colin, R., \& Grzbyk, M. (2017). Effect of occupational safety and health education received during schooling on the incidence of workplace injuries in the first 2 years of occupational life: A prospective study. BMJ Open, 7, e015100. https://doi:10.1136/bmjopen-2016-015100

Boyle, T. (2012). Health and safety: Risk management. Leicestershire: International Occupational Health and Safety Services limited Press. Retrieved from www.iosh.co.uk

Brown, T. A. (2015). Confirmatory factor analysis for applied research (2nd ed.). New York: Guilford Press.

Chatburn, E., Macrae, C., Carthy, J., \& Vincent, C. (2018). Measurement and monitoring of safety: Impact and challenges of putting a conceptual framework into practice. BMJ Quality Safety, 27(10), 818-826. https://doi.org/10.1136/bmjqs-2017-007175

Cohen, A., \& Colligan, M. (1998). Assessing occupational safety and health training: A review. Ohio: National Institute for Occupational Safety and Health Publication.

Fuller, C. W., \& Vassie, L. H. (2004). Health and safety management: Principles and practice (1st ed.). Leicester: Prentice Hall.

Fuller, T. P. (2019). Global occupational safety and health management handbook. Boca Raton: CRC Press. http://doi.org/10.1201/9780429056475

Gunningham, N. (2010). Enforcement and compliance strategies. Oxford: Oxford University Press. http://doi.org/10.1093/oxfordhb/9780199560219.003.0007

Hair, JR, J. F., Black, W. R., Babin, B. J., \& Anderson, R. E. (2010). Multivariate data analysis (7th ed.). Upper Saddle River, NJ: Prentice Hall.

Hurber-Carol, C., Balakrishman, N., Nikulin, M., \& Mesbah, M. (2002). Goodness-of-fit test and model validity (Eds.). Boston: Springer, Birkhauser. https://doi.org/10.1111/1541-0420.t01-1-00026

Katsuro, P., Gadzirayi, C. T., Taruwona, M., \& Mupararano, S. (2010). Impact of occupational health and safety on worker productivity: A case of Zimbabwe Food Industry. African Journal of Business Management, 4(13). 2644-265. Retrieved from http://www.academicjournals.org/AJBM

Kline, R. B. (2015). Principles and practice of structural equation modelling (4th ed.). New York: Guilford Press.

Lalis, A., \& Vittek, P. (2014). Safety KPIs monitoring of safety performance. Magazine of Aviation Development, 2(11), 9-15. https://doi.org/10.14311/MAD.2014.11.02

Lun, J. C., \& Wahab, S. R. (2017). The effect of safety leadership on safety performance in Malaysia. Saudi Journal of Business and Management Studies, 2(1), 12-18. https://doi.org/10.21276/sjbms.2017.2.1.3

Mashi, M. S., Subramaniam, C., \& Johari, J. (2016). The effect of safety training and workers involvement on healthcare workers safety behavior: The moderating role of consideration of future safety consequence. International Journal of Business Management, 1(2), 46-81.

Michael, J. B., Sarpy, S., A., Smoth-Crowe, K., Chan-Serafin, S., Salvador, R. O., \& Islam, G. (2006). Relative effectiveness of worker safety and health training methods. American Journal of Public Health, 96, 315-324. https://doi.org/10.2105/AJPH.2004.059840

Mubashar, M. J., Mufi, N. A., \& Amjad, M. (2013). The effect of safety training on safety culture in construction industry. International Journal of Engineering Research and Technology, 2(12), 641-647.

Reese, D. C. (2018). Occupational health and safety management: A practical approach (3rd ed.). Boca Raton: CRC Press. https://doi.org/10.1201/9781351228848

Tengilimoglu, D., Celik, E., \& Guzel, A. (2016). The effect of safety culture on safety performance: Intermediary role of job satisfaction. British Journal of Economics, Management and Trade, 15(2), 1-12. https://doi.org/10.9734/BJEMT/2016/29975

Umeokafor, N. I., Isaac, D., Jones, K., \& Umeadi, B. (2014). Enforcement of occupational safety and health regulations in Nigeria: An exploration. European Scientific Journal, 3, 1857-7881.

Umugwaneza, C., Nkechi, I., \& Mugabe, J. (2019). Effect of workplace safety and health practices on employee commitment and performance in Steel Manufacturing Companies in Rwanda. European Journal of Business and Management Research, 4(5), 1-11. https://doi.org/10.24018/ejbmr.2019.4.5.84 
Wambulwa, B. N., Makokha, E., N., \& Namusonge, G. (2018). Effect of occupational safety and health on organizational performance: A case of Nzoia Water in Trans-Nzoia Country. European Journal of Business and Management, 10(11), 47-56.

Yao, B., Zhu, L., Jiang, Q., \& Xia, A. (2013). Safety monitoring in clinical trials. Pharmaceutics, 5, 94-106. https://doi.org/10.3390/pharmaceutics5010094

Yusuf, R. M., Eliyana, A., \& Sari, O. N. (2012). The influence of occupational safety and health on performance with job satisfaction as intervening variables (Study on the Production Employees in PT. MahakaryaRotanindo, Gresik). American Journal of Economics, Special Issue, 136-140. https://doi.org/10.5923/j.economics.20120001.30

\section{Copyrights}

Copyright for this article is retained by the author(s), with first publication rights granted to the journal.

This is an open-access article distributed under the terms and conditions of the Creative Commons Attribution license (http://creativecommons.org/licenses/by/4.0/). 